American Journal of Agricultural and Biological Sciences 3 (4): 647-655, 2008

ISSN 1557-4989

(C) 2008 Science Publications

\title{
Extension Mechanisms to Support Sustainable Agriculture in Iran Context
}

\author{
Mohammad Sadegh Allahyari \\ Assistant professor \\ College of Agriculture, Islamic Azad University-Rasht Branch, Rasht, Guilan, Iran
}

\begin{abstract}
Sustainable agriculture, as a managerial philosophy has risen to meet environmental, economic and social complications. Agricultural extension as a source of information plays an important role for the achievement of sustainable forms of agriculture. In fact, conventional extension system cannot accomplish sustainability in agriculture. The objective of the study was to identify the most appropriate mechanism to support dimensions and policies of sustainable agriculture that used a descriptive-correlative design. The population of this study consisted of faculty members of agricultural extension education, extension head in provinces and extension specialists of deputy of agricultural extension and farming system in the Ministry of Agriculture in Iran. A sample consisting 87 respondents was selected through simple random sampling. The instrument used to achieve objectives of the study was a questionnaire by reliability 0.86 . Findings indicate that Iran's sustainable agricultural extension mechanisms are not favorable and the extension system does not pay enough attention to them. These conditions necessitate rethinking of extension mechanisms to accomplish sustainable agriculture. When examining the results of the Canonical correlation analysis, it reveals that the Wilks Lambda test was significant at 0.01 level. It indicates that the first squared Canonical correlation $\left(\mathrm{R}_{2} \mathrm{C} \mathrm{(1)}\right)$ was statistically significant. Based on the Canonical correlation analysis, on the predicator variables set, "assets of sustainable agriculture development", "supportive extension organizations toward sustainability", "content of sustainable agriculture extension" and "professionals of sustainable agriculture extension", loaded highest on Canonical function one and had the most impact upon policies and dimensions of sustainable agriculture.
\end{abstract}

Key words: Dimensions of sustainable agriculture, Sustainable agriculture extension, Extension mechanisms, Supportive policies

\section{INTRODUCTION}

In Iran, like other developing countries, agriculture is one of the most important economic sectors and comprises a considerably high percentage of production and employment. It accounts for over $1 / 4$ of the Gross National Product (GNP), 1/4 of employment, over $4 / 5$ of the domestic food supply, $1 / 3$ of non-oil exports (excluding carpet exports) and $9 / 10$ of the raw material demand of national industries ${ }^{[20]}$. Nevertheless, considering to dependency on pesticide and insecticide imports, a growing population, limited arable land, increasingly destruction of natural resources, soil erosion and degradation, water pollution, decreasing ground water tables and excessive use of chemical inputs led to unsustainable agricultural conditions in Iran $^{[2]}$.

Sustainable agriculture is a philosophy based on human goals and an understanding of the long-term impact of our activities on the environment and on other species ${ }^{[18]}$. It seems that sustainable agriculture is more than a shift in farming practices rather it must be focus on raising consciousness ${ }^{[33]}$. Knowledge and related information, skills, technologies and attitudes will play a key role in the sustainable agriculture ${ }^{[38]}$. Consequently, sustainable agriculture system is an information-intensive system ${ }^{[16]}$ because inputs have been replaced by skills, labors and management ${ }^{[7,8,21,25,29]}$. For example, in order for farmers that practice sustainable agriculture to be successful in managing their farmlands, there must be a continuous network of information, new technologies and innovations that are available to them. The extension service can play a crucial role in providing this network of information on sustainable agriculture education $^{[15]}$. Thus, the role of extension is very important to support sustainable agriculture $\mathrm{e}^{[1,19,35,38]}$. Nevertheless, there is a question: will the current agricultural extension system be able to accomplish sustainable agriculture? 
In Iran, like many other Middle Eastern countries, a mixed approach is used with a focus on governmental or common extension approaches. In Iran, the Transfer of Technology (ToT) model has been the prevalent practice for developing and spreading innovations. It is based on the assumption that a transfer of technology and knowledge from scientists to farmers will trigger development. Applied to agriculture, this model assumes that farmers' problems can be solved by people and institutions that have this "modern" knowledge. This top-down model creates a rigid hierarchy, which discourages the feedback of information. Researchers work independently of farmers and extension workers, resulting in a poor understanding of farmers and the opportunities and constraints they face. The transfer approach is fragmented, both institutionally and in terms of disciplines. Research concentrates on technology and researchers and extensionists are seen as technical agents. Social competence is not required as complex socio-organizational issues (e.g., land-use regulations, power structures, conflict resolution mechanisms) are neglected or reduced to a technical level ${ }^{[8,23]}$. It seems that with this system we cannot accomplish to sustainability, because of the traditional roles of transferring and disseminating of agricultural technologies are proving insufficient in today's global context ${ }^{[35]}$.

Historically, the rhetoric of agricultural extension worldwide has shifted from an emphasis on production, at the beginning of the century, to productivity (or efficiency) based agriculture, to the more recent philosophy of sustainability ${ }^{[20]}$. Extension systems have been gradually shifting from a knowledge transfer to a knowledge-share concept and farmers are no longer assumed as the sole recipients of new technology and science, instead, they are now contributing to the learning and teaching processes. The role of agricultural extension agents is also changing from transferring knowledge and technology to consultants, advisors and facilitators of the farmer learning process ${ }^{[20]}$. Pretty ${ }^{[25]}$ suggests that we are currently entering an era of social capital, where farmers are now considered to be the potential solution rather than the problem, i.e., the role of individual capacity is paramount. There has been a growing realization that traditional extension methods have not been sufficiently effective in promoting adoption of sustainable agriculture practices ${ }^{[36]}$. On this basis, the main purpose of this paper is to explore new extension mechanism to achieve sustainability. To accomplish this objective, after extensive literature review, we proposed following pattern (Fig. 1).

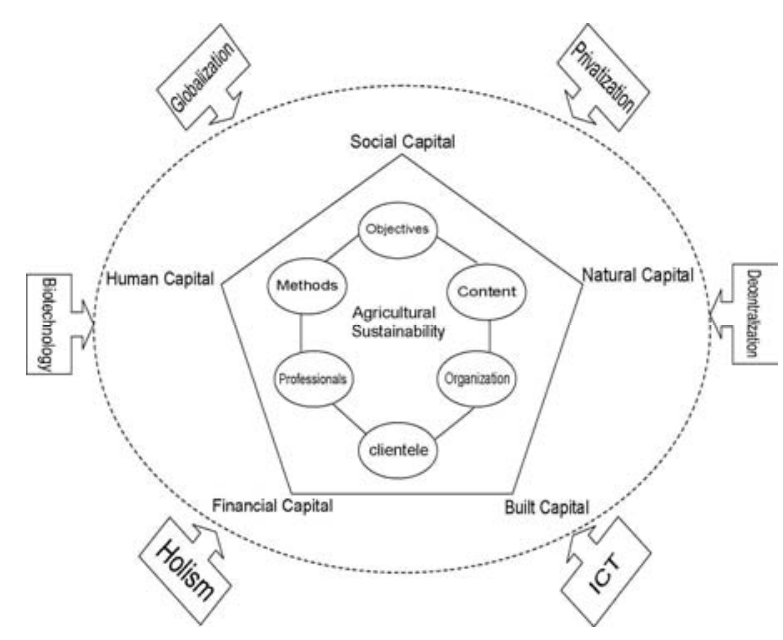

Fig. 1: Extension mechanisms to support agricultural sustainability

In this pattern, agricultural extension is seen as an Open Social System. First, we discuss about system perspective. What dose system perspective mean? According to Seepersad ${ }^{[32]}$, first, it emphasizes the need to view a situation as a whole and not as separate parts. Holism is, thus, a recurring theme. Indeed, system performance must be judged not simply in terms of how each part works separately, but in terms of how the parts fit together and relate to each other and in terms of how the system relates to its environment and to other systems in that environment ${ }^{[30]}$. Second, it recognizes the interactions of components inside the system as well as the effect of the immediate external environment upon the system in the process of transforming inputs to outputs. Finally, the systems perspective also stresses system hierarchy, whereby every system is part of a larger system and is itself composed of sub-system. In this model, forces of change are defined as external environment of system. The changes in the external environment force the extension organizations to make necessary adjustments if they want to continue functioning efficiently. The changes in the working environment, which be called as forces of change, vary in nature and scope, i.e., they could political, technical, economic or social. The effects of these forces of change are very important in dynamism of extension system toward sustainability, since the extension systems are directly or indirectly affected by the changes and, in response, must make internal and external adjustments in order to keep functioning at the same or higher level of efficiency to accomplish sustainability. In this model, the main forces of change, which are affecting or are, abound to affect the existing extension systems are: globalization and market 
liberalization, privatization, decentralization and participation, information and communication technology break-through, biotechnology and genetic engineering and holism perspective.

Sustainable agriculture systems are situationspecific systems ${ }^{[41]}$, thus, in order to support them, extension systems should be situation-specific, to ${ }^{[26]}$. The meaning of situation-specific is that sustainable agriculture systems should be acted base on the available assets ${ }^{[37]}$. In this pattern, we put these assets as the context of extension activities and functions to achieve sustainability, because of the success of extension systems is related to identify assets, assess their vulnerabilities and then take steps either to enhance and strengthen those assets or to reduce vulnerabilities placing stress on those assets ${ }^{[39,40]}$. These assets are human capital, social capital, natural capital, financial capital and built (manufactured) capital. Human capital refers to skills, abilities, education, indigenous knowledge and health of community. Social capital refers to the networks both within and outside the community, sense of place and belonging and the extent of opportunities exist for participation in local activities and decision-making. Natural capital refers to the existence and health of environmental assets. Financial capital refers to the financial resources in or available to the community. Built capital refers to community infrastructure ${ }^{[11,13]}$. Each form of capital can enhance the productivity of other forms of capital ${ }^{[11,12]}$. In addition, these assets are sub-system for forces of change and are interacting to them.

Components of extension system compose the internal part of the model. These components are as similar as the traditional components of extension systems, but based on the new paradigm of development we have defined new functions and objectives for them as they can support sustainability of agriculture. Within this paradigm, we cannot accomplish sustainable agriculture by only using conventional extension methods, rather it requires new kind of learning process that is called facilitation of learning ${ }^{[3,30]}$. Existing organizational frameworks mitigate against the emergence of the rural and agricultural sustainable development practices and to response to these challenges new network and organizations are emerging, as the key feature of new organizations is decentralization. Currently agricultural extension systems apply group methods, networking for exchanging and sharing information, socially and participatory learning methods etc. to facilitate learning of sustainable agriculture. Objectives of extension system is shifting toward enhancing adaptive management capacity, emancipation and social capital at local level, building of stakeholder platforms for negotiations, learning processes and food security. At the same time, extension clientele are more varied and shifted from large-scale farmers toward marginal and poor resource farmers, women and local groups. Ecologically sound practices, consequences of biotechnology and genetic engineering, trade liberalization, participation and new communication technologies will compose content of extension programs. Totally, participatory extension and action research approaches, which involved above-mentioned factors, have more ability to accomplish policies and dimensions of sustainable agriculture. Lastly, sustainability of agriculture composes the core of the model and it is an emergent property for the extension systems in changing world.

Based on the aforementioned pattern, the main purpose of this study was to identify the most appropriate extension mechanisms to support dimensions and policies of sustainable agriculture in Iran context.

\section{METRIALS AND METHODS}

Population and sample: The study represented descriptive-correlative survey research. The population for this study consisted of 170 faculty members of agricultural extension education, extension head in provinces and extension specialists of deputy of agricultural extension and farming system in the Ministry of Agriculture (Jihad-e-Keshavarzi) in Iran. The 87 of them were selected by random sample using the table for determining the sample from given population developed by Bartlett et al. ${ }^{[5]}$. The researchers verified the list before distribution of the survey to control for frame and selection threats to external validity.

Instrument: A mailed/e-mailed questionnaire was used to collect the data. Researchers developed this questionnaire. Questions were generated from the literature review. The instrument consisted of six separate sections according to the purpose and objectives of the study. The first section was designed to gather data on personal characteristics of extension specialists. The second section was designed to gather data concerning the necessity of attention on each of components of extension system (objectives, methods, organizations, extension agents and specialists, clientele and content of extension system) to accomplish sustainable agriculture in Iran agricultural extension system from extension specialists' perspective. In the 
third and fourth section were asked respondents to indicate the necessity of attention on each of assets and forces of change, respectively. These sections were about independent variables of research. Dimensions and policies of sustainable agriculture were dependents variables of this study. In section five and six were asked respondents to indicate their degree of agreement regarding the ability of extension system to accomplish dimensions and policies of sustainable agriculture, respectively. Responses for these sections were categorized using a five point Likert - type scale: $1=$ very low, $2=$ low, $3=$ medium, $4=$ much and $5=$ very much. The mean scores were used for later analysis (Canonical Analysis). An expert panel assessed the content validity of questionnaire. The panel included faculty members from Department of Agricultural Extension Education, The Islamic Azad UniversityTehran Science and Research branch and Tarbiat Modares University. Each of the experts on the panel was asked to examine the instrument for content, clarity, wording, length, format and overall appearance. Questionnaire reliability was estimated by calculating Cronbach's alpha. Reliability of the overall instrument was estimated at 0.86 , which can be regarded as sufficient.

Data collection and analyses: The data were collected between October 2006 and March 2007 through a questionnaire mailed or e-mailed to the 100 agricultural extension professionals. Those who failed to respond were sent a follow-up letter. Seventy nine agricultural extension professionals returned questionnaires yielding an overall response rate of $79 \%$. An early versus late respondent comparison was made to determine if no responses was a threat to validity of the study ${ }^{[22]}$.Using this procedure, no statistically significant differences between the groups were found. Therefore, findings from this study are assumed generalizable to the population from which it was drawn. Data collected were analyzed using the Statistical Package for the Social Sciences (SPSS, 14). Appropriate descriptive statistics such as mean scores and standard deviations were used to analysis the data generated. Inferential statistics such as Pearson correlation, Canonical Correlation were used to analysis data.

\section{RESULTS AND DISCUSSION}

The ages of the respondents ranged from 25-63. The mean age was $38(\mathrm{SD}=8.87, \mathrm{~N}=79)$. The majority $(39.2 \%, \mathrm{n}=31)$ of respondent were $31-40$ years old. Most of the respondents in the study were male $(93.7 \%)$ and only five persons $(6.3 \%)$ were female. The years of experience of respondents ranged from 2-30. The mean years served in extension were $12.4(\mathrm{SD}=8.75)$. Nearly one-third of agricultural extension professionals $(29.1 \%)$ had served in extension for $1-5$ years. $29.1 \%$ of extension specialists had a doctoral degree in agricultural extension and education discipline and $62 \%(n=49)$ of respondents were a masters degree holders. only $8.9 \%$ of extension specialists had a bachelor's degree $(\mathrm{n}=7) .35 .4 \%$ of respondents $(\mathrm{n}=28)$ were faculty members and $15.25 \%$ $(\mathrm{n}=12)$ had a managerial position. Remain were extension experts (49.35\%). 35.4\% of respondents worked at universities, $27.8 \%(\mathrm{n}=22)$ worked at agriculture ministry. 29.1\% $(\mathrm{n}=23)$ of extension specialists worked in agricultural extension services at province level and remain worked at county level $(6.3 \%)$.

Based on the descriptive findings, objectives of extension system was the most important component for the achievement of sustainable agriculture $(\mathrm{M}=$ 4.54, SD = 0.45). Empowerment, food security and enhancing adaptive management capacity can be addressed as the first objectives for the extension system to achieve sustainability in Iran's agriculture. In the next step, extension professionals $(\mathrm{M}=4.48, \mathrm{SD}=$ $0.54)$ and content of extension programs $(M=4.48, S D$ $=0.54)$ had the highest roles to accomplish agricultural sustainability. Iranian agricultural extension experts believed that to generate a proper context for development of sustainable agriculture, in first step, extension system should be paid attention to create or strengthen human capital at very much level and in second step, it should be attention to social capital. The existence and health of environmental assets, financial and built assets were in the next steps, respectively. Regarding forces of change, $92.4 \%$ of respondents were ranked holism perspective as the first challenge for the extension rethinking toward sustainable agriculture. They reported new Information and Communication Technologies (ICT) $(\mathrm{M}=4.53, \mathrm{SD}=0.82)$ and participation and decentralization $(\mathrm{M}=4.51, \mathrm{SD}=$ 0.72 ) as the future important challenges to design sustainable extension system in Iran context. In addition, the relatively lowest item mean value $(\mathrm{M}=$ $4.05, \mathrm{SD}=0.96)$ in this area was reported for the privatization (Table 1).

There were two groups of dependent variables in this study: supportive policies of sustainable agriculture $^{[4,25]}$ and dimensions of sustainable agriculture $^{[41]}$. The mean value of the overall (summated across the 24 items) perceptions of the extension experts regarding the ability of extension system to achieve supportive policies of sustainable agriculture was 4.28 , the standard deviation was 0.65 . 
Am. J. Agri. \& Biol. Sci., 3 (4): 647-655, 2008

Table 1: Descriptive statistics of predicator and criterion variables in Canonical Correlation Analysis

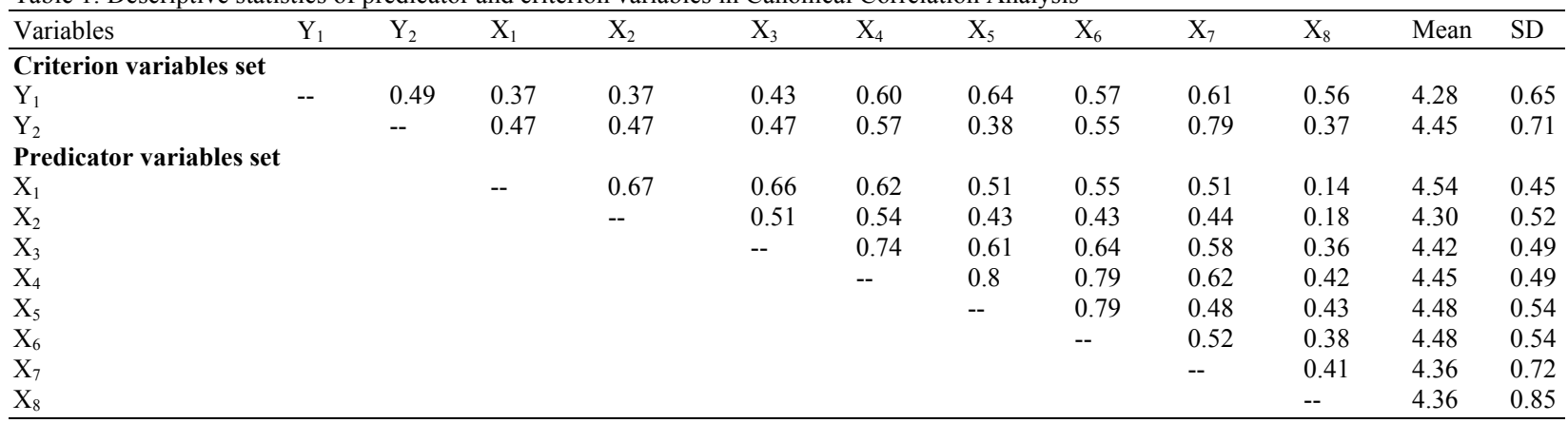

$\mathrm{Y}_{1}$ : Supportive policies of sustainable agriculture, $\mathrm{Y}_{2}$ : Dimensions of sustainable agriculture, $\mathrm{X}_{1}$ : Objectives of extension system, $\mathrm{X}_{2}$ : Clientele of extension system, $\mathrm{X}_{3}$ : Extension methods, $\mathrm{X}_{4}$ : Supportive extension organizations, $\mathrm{X}_{5}$ : Professionals of extension, $\mathrm{X}_{6}$ : Content of extension programs, $\mathrm{X}_{7}$ : Assets of sustainable agriculture and $\mathrm{X}_{8}$ : Forces of change

This overall value indicates that the extension experts generally had a positive perception toward the ability of extension system to achieve supportive policies of sustainable agriculture. Assessment of respondents replies regarding the ability of extension system to achieve dimensions of sustainable agriculture (environmental, economic and social) indicated that the economic dimension had the highest mean value $(\mathrm{M}=$ $4.52, \mathrm{SD}=0.60$ ). The second highest area mean value $(\mathrm{M}=4.48, \mathrm{SD}=0.70)$ was the environmental dimension. From extension professionals' viewpoints the ability of extension system to achieve social dimension was in third rate $(\mathrm{M}=4.34, \mathrm{SD}=0.84)$.

The main objective of this study was to describe the relationship of forces of change, assets and components of extension system to dimensions and policies of sustainable agriculture. This objective was met by using the Canonical correlation procedure. Canonical correlation analysis, a technique that allows for the investigation of multiple independent variables effects upon multiple dependent variables ${ }^{[31]}$. Canonical correlation is considered to be the general model on which many other multivariate techniques are based because it can use both metric and nonnumeric data for either the dependent or independent variables ${ }^{[14,17]}$. In addition, The Canonical correlation analysis can be applied to determine the impacts of forces of change, assets and components of extension system as independent variables upon dimensions and policies of sustainable agriculture as dependent variables. Before starting the canonical analysis, a correlation analysis was carried out to avoid problems with multicolinearity. Since correlations between the eight predictors did not exceed 0.8 , we kept all predictors in the canonical analysis ${ }^{[28]}$. As seen in Table 1, of the intercorrelations among the predicator variables set, high correlations ${ }^{[9]}$ were found between Supportive extension organizations and Extension methods $(\mathrm{r}=0.74)$ and extension
Table 2: Canonical correlation analysis

\begin{tabular}{llllrl}
\hline Function & Eigen value & Canon. Corre. & Canon. Corr. ${ }^{2} \mathrm{~F}$ & $\mathrm{P}$ \\
\hline 1 & 3.88 & 0.899 & 0.795 & 13.8 & 0.000 \\
2 & 0.385 & 0.527 & 0.278 & 3.8 & 0.001 \\
\hline
\end{tabular}

Professionals and Supportive organization $(\mathrm{r}=0.8)$. In addition, moderate to high correlations ${ }^{[9]}$ were discovered between other predicator variables set, from $r=0.37$ to $r=0.67$. Substantial correlations were also discovered between Dimensions of sustainable agriculture and Assets of sustainable agriculture $(\mathrm{r}=$ 0.79). The lowest correlations were found between Dimensions of sustainable agriculture and Forces of change $(r=0.37)$, but Supportive policies had the highest correlations with Extension professionals $(r=$ 0.64). Moderate correlations were discovered between Supportive policies and Dimensions of sustainable agriculture $(\mathrm{r}=0.49)$. The matrix of correlation indicated that interactions between different parts of the model as a mechanism for extension system toward sustainability were significant and underpins the necessity of attention to system perspective in sustainability issues.

Table 2 indicates two functions (two pairs of varieties) were derived yielding various canonical correlation scores. When examining the results of the canonical correlation analysis, it reveals that the Wilks Lambda test was significant at 0.001 level. It indicates that both squared canonical correlation $\left(\mathrm{R}^{2}{ }_{C(1)}\right.$ and $\mathrm{R}_{\mathrm{C}(2)}^{2}$ ) were statistically significant. In addition, following the $10 \%$ rule of thumb ${ }^{[6,10]}$, both squared canonical correlation coefficient $\left(\mathrm{R}_{c(1)}^{2}=0.795\right.$ and $\left.\mathrm{R}_{\mathrm{c}(2)}^{2}=0.278\right)$ were more than 0.1 and were meaningful, too (Table 2).

Canonical weights (standardized canonical coefficients) were used as indices of the relative importance of a variable to the function. The researchers selected the variables, which indicated a 
Am. J. Agri. \& Biol. Sci., 3 (4): 647-655, 2008

Table 3 summary of canonical correlation analysis

\begin{tabular}{|c|c|c|c|c|}
\hline \multirow[b]{2}{*}{ Variables } & \multicolumn{2}{|c|}{ Canonical Root 1} & \multicolumn{2}{|c|}{ Canonical Root 2} \\
\hline & $\mathrm{b}$ & $\mathrm{s}$ & $\mathrm{b}$ & $\mathrm{s}$ \\
\hline \multicolumn{5}{|l|}{ Criterion variables set: } \\
\hline Supportive policies of sustainable agriculture & 0.434 & 0.748 & -1.063 & 0.621 \\
\hline Dimensions of sustainable agriculture & 0.713 & 0.926 & 0.90 & 0.378 \\
\hline \multicolumn{5}{|l|}{ Predicator variables set: } \\
\hline Objectives of sustainable agriculture extension system & -0.019 & 0.558 & 0.041 & 0.056 \\
\hline Clientele of sustainable agriculture extension system & 0.134 & 0.552 & 0.121 & 0.055 \\
\hline Supportive extension methods for sustainable agriculture & -0.207 & 0.588 & 0.104 & -0.066 \\
\hline Supportive extension organizations for sustainable agriculture & 0.119 & 0.748 & 0.119 & -0.240 \\
\hline Sustainable agriculture extension professionals & -0.140 & 0.611 & -0.367 & -0.646 \\
\hline Content of sustainable agriculture extension programs & 0.360 & 0.722 & 0.489 & -0.215 \\
\hline Assets of sustainable agriculture development & 0.708 & 0.935 & 0.456 & 0.131 \\
\hline Forces of change & 0.201 & 0.570 & 0.422 & -0.439 \\
\hline PV & & 0.451 & & 0.098 \\
\hline Redundancy & & 0.585 & & 0.073 \\
\hline $\mathrm{R}_{\mathrm{C}}^{2}$ & & 0.795 & & 0.278 \\
\hline
\end{tabular}

Note: $\mathrm{b}=$ standardized canonical coefficient, $\mathrm{s}=$ structure coefficient

relatively high coefficient in relation to the other variables within a given function. Table 3 indicates that for the criterion variable set, "Dimensions of sustainable agriculture" was most important (0.713) for canonical function 1. For the predicator variable set "Assets of sustainable agriculture", (0.708) and "Content of extension programs" (0.360) were relatively important for function 1 .

The structure coefficients can be interpreted in a manner identical to factor interpretation in factor analysis. The rule of thumb ${ }^{[6,10,24,27]}$ is to treat as meaningful structure coefficients, which are equal to or greater than 0.3 . The magnitude of the structure coefficients were interpreted following guidelines: 0.25 or lower, Low, $0.25-0.64$, Moderate and 0.65 or greater, High. On the criterion variable set, both "Dimensions of sustainable agriculture" (0.926) and "Supportive policies" (0.748) variables loaded highest on canonical variate 1 . Of the predicator variable set, "Assets of sustainable agriculture" (0.935), "Supportive extension organizations" (0.748) and "Content of extension programs" (0.722) loaded highest on canonical function 1 (Table 3). Since in function 2, most of the structure coefficients were less than 0.3 , this function was not important and we did not interpret this function.

Based on the findings, the degree of attention to assets as a context for development of sustainable agriculture had the most effect to accomplish criterion variables. Human and social capitals are the most important capitals among the assets of sustainable agriculture. In the first step, thus, for the achievement of dimensions and policies of sustainable agriculture, extension system should be paid more attention to create or reinforce of human capital. Human capital encompasses skills, abilities, education, indigenous knowledge, improved nutrition and health of community. Then, it can be concluded that emphasizing on the farmers skills and education is the most important role for extension systems toward accomplishment of the sustainability. This educating should be focused on the interrelationship among agricultural production, food security, population and environment and the agro-ecological practices. The supportive extension organizations was the second predicator variable that had effective role to achieve dimensions and policies of sustainable agriculture. The results revealed that the best characteristics for supportive organizations regarding sustainable agriculture were: attendance of farmers associations, collaboration among research, extension-education organizations, farmers' associations, NGOs, rural credit agencies and transportation companies, learning organizations and emergence of pluralistic approaches and inter-institution linkages (collaboration among public sector, private sector and NGOs), respectively ${ }^{[2]}$. In addition, all of these characteristics are symbols of social capital too ${ }^{[34]}$. Extension systems should be provided suitable content for the extension program to support sustainability. This content must be selected based on the need assessment, and the subjects can be included in extension programs are interrelationship among agricultural production, food security, population and environment, agro-ecological practices, problem solving, decision making, management, accounting, group dynamics, leadership, participation, gender sensitiveness, applicable of information technology and networking, etc. 


\section{COCLUSIONS}

For the sustainable agriculture development in Iran, there is a greater need for reorientation in agricultural extension systems. From the aforementioned results, it is concluded that agricultural extension systems toward accomplishment of sustainability should be departed from reductionism thoughts ${ }^{[3]}$ and they must focus on holism and systemic perspectives. Respondents believed that the success and dynamism of system based-extension models depends on the identifying of environment and context of systems and the interactions that occur among them. Based on the pointed out pattern in this study, forces of change will be affected on the extension functions and dynamism of extension systems depend on the adaptation of these systems with these challenges. Systemic and holism perspective, new communication and information technology, participation and decentralization are the most important challenges that have an effect on the components of extension system toward accomplishment of sustainability within agriculture. Therefore, it would be necessary to train extension workers that they can be able to adapt whit these challenges. Identifying assets of agricultural sustainable development as a context for the functions of extension systems play key role for the achievement of sustainability, so that they known as the gene of model. Amongst these assets, human and social capital should be gave more attention rather than other assets. Finally, re-thinking in agricultural extension components is mandatory and we must strive to find new functions, strategies and objectives for extension systems toward sustainability.

\section{REFERENCES}

1. Ahmadvand, M. and E., Karami, 2007. Sustainable agriculture: Toward a conflict, management based agricultural extension. J. Applied Sci., 7: 38803890. Doi: 10.3923/jas.2007.3880.3890

2. Allahyari, M.S. and M., Chizari, 2008. Supportive organizations regarding environmentally sound agriculture in Iran. Green Farm. J., 1: 14.:http://www.greenfarming.in/PreviousIssues/Mar ch-2008.pdf

3. Allahyari, M.S. and M. Chizari, 2008. Role of extension-education methods to support dimensions of agricultural sustainability, Green Farm.J.,1:6-10. http://www.greenfarming.in/Previous-Issues/April2008.pdf
4. Allahyari, M.S. and M., Chizari, 2008. Ability of extension system to accomplish supportive policies of sustainable agriculture in Iran. J. Applied Sci., 8: 3064-3067. Doi: 10.3923/jas.2008.3064.3067

5. Bartlett, J.E., J.W., Kotrlik and C.C. Higgins, 2001. Organizational research: Determining appropriate sample size in survey research. Info. Technol., Learning Performance, J. 19:43-50. http://www.osra.org/itlpj/bartlettkotrlikhiggins.pdf.

6. Cano, J., 1990. The relationship between instruction and student performance at the various levels of cognition among selected Ohio production agriculture programs. J. Agric. Educ., 31:74-80.

http://pubs.aged.tamu.edu/jae/pdf/Vol31/31-02 74.pdf

7. Chizari, M., J.R., Lindner and M. Zoghie, 1999. Perceptions of extension agents' educational needs regarding sustainable agriculture in the Khorasan Province, Iran. J. Agric. Educ., 40: 20-27. http://pubs.aged.tamu.edu/jae/pdf/Vol40/40-04 20.pdf

8. Cho, K.M. and H., Boland, 2004. Education and extension for multi-functional agriculture: Extension concepts for sustainable agricultural development in Myanmar. In: proceedings of 20th Annual Conference of AIAEE, 23-29 May 2004. Dublin, Ireland, pp: 531-537. http://www.aiaee.org/2004/Accepted/069.pdf

9. Davis, J.A., 1971. Elementary Survey Analysis. ${ }^{\text {st }}$ Edn. Englewood Cliffs, NJ, Prentice-Hall. ISBN: 0132605473.

10. Farshadfar, E., 2005. Principals and Methods of Multivariate Statistics ( ${ }^{\text {st }}$ edition). Taghbostan press, Kermanshah. ISBN: 1-95-5551-964

11. Flora, B.C., 1997. Enhancing community capitals: The optimization equation. Rural Dev. News, 21(1).

http://www.ncrcrd.iastate.edu/newsletter/mar97/en hance.comm.cap.html

12. Flora, B.C., 1997. Building social capital: The importance of entrepreneurial social infrastructure. Rural Dev. News, 21(2). http://www.ncrcrd.iastate.edu/newsletter/june97/bu ild-soc-capital.html

13. Gasteyer, S.P. and et al. 2002. Community participation for conservation and development of natural resources: A summary of literature and report of research findings. Delta Dev. J., 1: 56-78. http://www.ncrcrd.iastate.edu/pubs/flora/articles/de ttajournal57-84.pdf

14. Hair, J.F., B., Black, B., Babin, R.E. Anderson and R.L. Tatham, 2005. Multivariate Data Analysis. 6th Edn., Florida: Englewood Cliffs, NJ., Prentice Hall, ISBN: 8177585738 
15. Hersman, E.M., 2004. Knowledge and Dissemination of Sustainable Agriculture Practices by County Extension Agents in Ohio, Pennsylvania and West Virginia. Master's Thesis, Davis College of Agriculture, Forestry and Consumer Sciences, West Virginia University. https://eidr.wvu.edu/files/3398/Hersman_Erin thes is.pdf

16. Ingram, J., 2008. Agronomist-farmer knowledge encounters: An analysis of knowledge exchange in the context of best management practices in England. Agric Hum Values, 25: 405-418. Doi: 10.1007/s10460-008-9134-0.

17. Kalantari, K., 2002. Data Processing and Analysis in Socio-Economic Research. $1^{\text {st }}$ Edn. Sharif Publication, Tehran. ISBN: 963-5649-23-4.

18. Karami, E. and A. Mansoorabadi, 2008. Sustainable agricultural attitudes and behaviors: A gender analysis of Iranian farmers. Environ. Dev. Sustainability, Doi: 10.1007/s10668-007-9090-7.

19. Karami, E., 1995. Agricultural extension: The question of sustainable development in Iran. J. Sustainable Agric., 5: 61-72. Doi: 10.1300/J064v05n01_05

20. Karbasioun, M., 2007. Towards a competency profile for the role of instruction of agricultural extension professionals in Esfahan. $1^{\text {st }}$ Edn. Wageningen University and Research Centre, the Netherlands. Wageningen. ISBN: 90-8504-602-5. http://library.wur.nl/wda/dissertations/dis4170.pdf

21. Lawrence, A. and C., Garforth, 1997. Supporting sustainable agriculture through extension in Asia. Natural Resource Perspectives. No 21, London: ODI.

http://www.odi.org.uk/resources/specialist/naturalresource-perspectives/21-sustainable-agricultureextension-asia.pdf

22. Lindner, J.R., T.H., Murphy and G.E. Briers, 2001. Handling Non-response in social science research. J. Agric. $\quad$ Educ., 42: 43-53. http://pubs.aged.tamu.edu/jae/pdf/Vol42/42-0443.pdf

23. Moyo, E. and J. Hagmann, 2000. Facilitating competence development to put learning process approaches into practice in rural extension. In: Human Resources in Agriculture and Rural Development, FAO, ISBN: 92-5-004469-0. http://www.picoteam.org/publications/pdf/Facilitati ng\%20Competence\%20Development-2000.pdf

24. Myaskovsky, L., M.A. Dew, G.E. Switzer, M.L. McNulty, A.F. Di Martini and K.R. McCurry, 2005. Quality of life and coping strategies among lung transplant candidates and their family caregivers. Soci. Sci. Med., 60: 2321-2332. Doi:10.1016/j.socscimed.2004.10.001
25. Pretty, J.N., 1995. Regenerating agriculture. Policies and Practice for Sustainability and SelfReliance. $1^{\text {st }}$ Edn. London, Earthscan. ISBN: 96490708-4-2

26. Qamar, M.K., 2002. Global trends in agricultural extension: challenges facing Asia and the Pacific region. Rome: FAO, Sustainable Development Department(SD).

http://www.fao.org/sd/2002/KN0903a2 en.htm

27. Roberts, T.G. and J.E. Dyer, 2005. The relationship of self-efficacy, motivation and critical thinking disposition to achievement and attitudes when an illustrated web lecture is used in an online Learning environment. J. Agric. Educ., 46: 12-23. http://pubs.aged.tamu.edu/jae/pdf/Vol46/46-02 12.pdf

28. Rogge, E., F., Nevens and H., Gulinck, 2007. Perception of rural landscapes in Flanders: Looking beyond aesthetics. Landscape Urban Plann., 82: 159-174. Doi:10.1016/j.landurbplan. 2007.02.006.

29. Roling, N.G., 1994. Facilitating Sustainable agriculture: turning policy models upside down. In: Beyond Farmer First, Rural People's Knowledge, Agricultural Research and Extension Practices, Scoones, I. and J. Thompson (Eds.). Intermediate Technology Publications, London, pp: 467-473. ISBN: 964-94103-1-7

30. Roling, N.G. and M.A.E. Wagemakers, 1998. Facilitating Sustainable Agriculture, Participatory Learning and Adaptive Management in times of Environmental Uncertainty. $1^{\text {st }}$ Edn. Cambridge University Press. Cambridge. ISBN: 0-521-794811

31. Schul, P.L., W.M. Pride and T.L. Little, 1983. The impact of channel leadership behavior on intrachannel conflict. J. Market. 47: 21-34. http://www.jstor.org/pss/1251194

32. Seepersad, J., 1994. Improving agricultural extension through a systems approach: Lessons from the Caribbean agricultural extension project. J. Int. Agric. Extension Educ., 1: 22-27. http://www.aiaee.org/archive/Vol-1.2.pdf

33. Somers, N. 1998. Learning about sustainable agriculture: The case of Dutch arable farmers. In N.G. Roling and M.A.E. Wagemaker (Ed). Facilitating sustainable agriculture, Cambridge, Cambridge University. ISBN : 0-521-79481-1.

34. Swanson, B.E. 2006. The changing role of agricultural extension in globally economy. J. Int. Agric. Extension Educ., 13: 5-18. http://www.aiaee.org/archive/Vol-13.3.pdf

35. Toness, A.S., 2001. The potential of Participatory Rural Appraisal (PRA) approaches and methods for agricultural extension and development in $21 \mathrm{st}$ century. J. Int. Agric. Extension Educ., 8: 25-37. http://www.aiaee.org/archive/Vol-8.1.pdf 
36. Vanclay, F. and G. Lawrence, 1995. Agricultural extension as social welfare. Rural Soci., 5(1):2035.http://rsj.e-

contentmanagement.com/archives/vol/5/issue/1/arti cle/1405/agricultural-extension-as-social-welfare

37. Van Loon, G.W., S.G. Patil and L.B., Hugar, 2005. Agricultural Sustainability, Strategies for Assessment. $1^{\text {st }}$ Edn. Sage Publication, New Delhi. ISBN: 0-7619-3340-9.

38. World Bank 2005. Agriculture Investment Sourcebook. $1^{\text {st }}$ Edn. Washington DC., World Bank. ISBN: 0-8213-6085x [Online]. Available from: www.worldbank.org/agsourcebook.
39. Worth, S., 2006. Agriflection: A learning model for agricultural extension in South Africa. J. Agric. Educ. Extension, 12: 179-193. Doi: $10.1080 / 13892240600915488$

40. Worth, S., 2002. Sustainable extension: Not transforming, but renewal. Proceedings of the 18th Annual Conference of AIAEE, 26-30 May 2006, Durban, South Africa, pp: 473-480. http://www.aiaee.org/2002/worth473-480.pdf

41. Zhen, L. and J.K. Routray, 2003. Operational indicators for measuring agricultural sustainability in developing countries. Environ. Manage., 32: 34-46. Doi: 10.1007/s00267-0032881-1. 